\section{Germination of Phlox pilosa L. Seeds Is Improved by Gibberellic Acid and Light but Not Stratification, Potassium Nitrate, or Surface Disinfestation}

\author{
Angela M. Madeiras ${ }^{1,3}$, Thomas H. Boyle ${ }^{2}$, and Wesley R. Autio ${ }^{2}$ \\ Department of Plant, Soil and Insect Sciences, Bowditch Hall, University of \\ Massachusetts, Amherst, MA 01003
}

Additional index words. Phlox pilosa, germination, $\mathrm{GA}_{3}$, potassium nitrate, stratification, light, disinfestation

\begin{abstract}
The effects of warm stratification and cold stratification, gibberellin-3 (GA 3 ) concentration, potassium nitrate concentration, light, and duration of surface sterilization on the germination of downy phlox (Phlox pilosa L.) seeds were studied. Germination after 21 days (G21), days to $50 \%$ germination $\left(T_{50}\right)$, and number of days between $10 \%$ and $90 \%$ final germination $\left(T_{90}-T_{10}\right)$ were calculated for each treatment. Total germination percentage was most significantly improved by cold stratification at $5 \pm 2{ }^{\circ} \mathrm{C}$ for 10 weeks after warm stratification at $20^{\circ} \mathrm{C}$ for 2 weeks; however, a substantial amount of germination occurred during the prestratification period, thus resulting in a crop with poor uniformity. A total of $10 \mathrm{mg} \cdot \mathbf{L}^{-1} \mathbf{G A}_{3}$ significantly improved the $\mathbf{G} 21, \mathbf{T}_{50}$, and $T_{90}-T_{10}$ values. Although $G_{3}$ concentration and duration of cold stratification period interacted significantly when the two were combined, the additive effects of $\mathrm{GA}_{3}$ and cold stratification did not significantly improve $\mathbf{G 2 1}$ values over those obtained with $\mathbf{G A}_{3}$ alone nor were $T_{50}$ values improved over those obtained with cold stratification alone. Potassium nitrate did not influence the $T_{50}$ and $T_{90}-T_{10}$ values and improved G21 only slightly. Light was found to be necessary for germination. Surface sterilization with $10 \%$ bleach decreased the growth of fungi on seeds but had no significant effect on the germination responses of $P$. pilosa seeds. Application of $\mathrm{GA}_{3}$ at $10 \mathrm{mg} \cdot \mathrm{L}^{-1}$ is a promising method for improving seed germination in perennial Phlox species.
\end{abstract}

The genus Phlox consists of $\approx 60$ species native to North America (Steffey, 1987; Wherry, 1955). The "Phlox pilosa complex," a taxonomic grouping considered to be a natural phyletic unit, consists of four species: P. pilosa, P. divaricata, P. amoena, and $P$. floridana (Levin, 1966; Wherry, 1955). The perennial species Phlox pilosa (also known as Prairie Phlox or Downy Phlox) consists of several subspecies (Levin, 1966). All species in the "Phlox pilosa complex" are self-incompatible, but there is a great deal of compatibility and potential for outcrossing within the complex (Levin, 1966).

Wildflowers are now widely used in residential and commercial landscaping, habitat restoration, and highway beautification projects (Milstein, 2005). Phlox pilosa is potentially useful in these situations. This species is found in all states from North Dakota to Texas and eastward into Florida and New York (Barkley, 1986). Germination of $P$. pilosa seeds is erratic (Specialty Perennials, 2006), and poor seedling emergence

\footnotetext{
Received for publication 30 Jan. 2007. Accepted for publication 20 Mar. 2007.

${ }^{1}$ Graduate research assistant.

${ }^{2}$ Professors

${ }^{3}$ To whom reprint requests should be addressed; e-mail madeiras@mail.uri.edu
}

in its natural habitat has been reported (Christiansen, 1967). The inconsistent germination of many perennial species has long discouraged growers from starting plants from seed; however, several companies have recently begun to focus on improving germination of perennial species through seed treatments (Hamrick, 2005).

Although considerable research has been done on seed germination of the annual species $P$. drummondii (Carpenter et al., 1993a, 1993b, 1995), there is a paucity of scientific literature concerning germination in the perennial Phlox species. Several seed companies have published recommendations for germinating perennial Phlox seeds. For example, Prairie Moon Nursery (2004) suggests cold stratification at 33 to $38^{\circ} \mathrm{F}$ ( 0 to $5{ }^{\circ} \mathrm{C}$ ) for 2 months to break dormancy in $P$. pilosa seeds. Specialty Perennials (2006) recommends freezing $P$. pilosa seed for 2 weeks before sowing, then incubating seed trays in darkness at $70^{\circ} \mathrm{F}\left(20^{\circ} \mathrm{C}\right)$ for 3 weeks, followed by $35^{\circ} \mathrm{F}\left(2{ }^{\circ} \mathrm{C}\right)$ for 3 weeks before moving trays back to $70{ }^{\circ} \mathrm{F}\left(20{ }^{\circ} \mathrm{C}\right)$. Similarly, Jelitto Staudensamen (2004) recommends prestratification of $P$. pilosa seeds at 18 to $22^{\circ} \mathrm{C}$ in moist medium for 2 to 4 weeks, followed by cold stratification at -4 to $4{ }^{\circ} \mathrm{C}$ for 4 to 6 weeks, and a period (duration not specified) of moderate temperatures ( 5 to $12{ }^{\circ} \mathrm{C}$ ) before exposure to warmer temperatures. Simplification of these procedures would be beneficial to commercial growers and seed producers. The Association of Official Seed Analysts (AOSA) makes recommendations for germinating $P$. drummondii but no other Phlox species (AOSA,1988).

Germination rate and uniformity of many wildflower species can be improved by cold stratification (Baskin and Baskin, 1998; Bratcher et al., 1993; Wartidiningsih et al., 1994). In their germination study of 91 Wisconsin prairie species, Greene and Curtis (1950) observed that germination of Phlox pilosa seeds increased from $2 \%$ to $10 \%$ after stratification at $40{ }^{\circ} \mathrm{F}\left(6{ }^{\circ} \mathrm{C}\right)$ for 3 months. The majority of prairie species tested by these researchers responded positively to cold stratification.

Release from dormancy by cold stratification is indicative of physiological dormancy, a condition in which the embryo lacks the ability to penetrate the seedcoat (Baskin and Baskin, 2005). Physiological dormancy is found in numerous plant families. Baskin and Baskin (2005) classify seeds in this category as having deep, intermediate, or nondeep physiological dormancy, depending on the temperature requirements for dormancy break, response to gibberellins, and the growth of embryos excised from seeds. The germination of some species with physiological dormancy is enhanced by a period of warm stratification (temperature not specified) before cold stratification (Baskin and Baskin, 2005).

In some species, cold stratification can replace a light requirement for germination (Bewley and Black, 1994). Recent studies have revealed that cold stratification has a direct effect on production of gibberellins (GAs) in seeds of Arabidopsis thaliana (Yamaguchi and Kamiya, 2000, 2002; Yamauchi et al., 2004). Exogenously applied $\mathrm{GA}_{3}$ overcomes seed dormancy in several species (Baskin and Baskin, 1998; Hartmann et al., 1997) and promotes germination in some species that normally require cold stratification, light, or after-ripening (Bewley and Black, 1994). GA promotes the production of enzymes such as endo- $\beta$-mannanase, which loosen cell walls in the endosperm, thereby reducing resistance to radicle emergence (Bewley, 1997; Groot and Karssen, 1987: Yamaguchi and Kamiya, 2002).

In addition to its role in plant nutrition, nitrate acts as a signal molecule in several processes in plant development and metabolism (Wang et al., 2003). A solution of $0.2 \%$ potassium nitrate has been found to enhance germination of Phlox drummondii (Heit, 1957); however, Springer and Tyrl (1989) observed no significant enhancement of germination in seeds of $P$. oklahomensis treated with $0.2 \% \quad \mathrm{KNO}_{3}$. Exogenously applied nitrate enhanced germination in Arabidopsis (Alboresi et al., 2005; Hilhorst and Karssen, 1988). Batak et al. (2002) found that exogenously applied nitrate reduced the light requirement for germination in seeds of Arabidopsis Landsberg erecta ecotype. The degree of dormancy in Arabidopsis seeds is correlated with nitrate nutrition of the mother 
plant and with the nitrate content of seeds themselves; the greater the available nitrate, the lower the dormancy (Alboresi et al., 2005). Nitrate accumulation in Arabidopsis seed is also correlated with a decreased requirement for GAs during germination (Alboresi et al., 2005).

Pathogenic fungi, bacteria, and viruses may be found on seedcoats or within seed tissues. Seedborne fungi may cause poor germination and impair seedling development (Halmer, 2000). Certain species of Alternaria can infect seed while it is still on the mother plant and can be responsible for decreased germination (Mycock and Berjak, 1995).

The present study was conducted to determine the effects of cold stratification with prestratification, $\mathrm{GA}_{3}$, potassium nitrate, light, and surface disinfestation on the germination of Phlox pilosa seeds.

\section{Materials and Methods}

Germination methods. Phlox pilosa seeds were obtained from Prairie Moon Nursery (Winona, MN). Seeds were sown in 9-cm glass petri dishes on top of a single layer of blue blotter paper (Anchor Paper Company, St. Paul, MN). Except for Expts. 5 and 6, all seeds were treated one day after sowing with $3 \alpha, 4,7,7 \alpha$-tetrahydro-2-[(trichloromethyl) thio]$1 H$-isoindole-1,3(2H)-dione (captan), $50 \%$ wettable powder, formulated product at $0.24 \mathrm{mg} / 100 \mathrm{~mL}$ deionized water. Seeds in Expt. 5 were treated with captan on the day of sowing. Seeds in Expt. 6 were not treated with captan. Germination tests were performed in a growth chamber (model I35LVL; Percival Scientific, Boone, IA) at $20{ }^{\circ} \mathrm{C}$ constant temperature with cool-white fluorescent lamps providing $50 \pm 8 \mu \mathrm{mol} \cdot \mathrm{m}^{-2} \cdot \mathrm{s}^{-1}$ photosynthetic photon flux $(P P F)$. The photoperiod was $12 \mathrm{~h}$ per $24-\mathrm{h}$ cycle in all experiments. Placement of petri dishes in the incubator was completely randomized. Blotter paper was moistened as needed with deionized water.

Data collection. Four 50-seed replicates were used for each treatment unless stated otherwise. In all experiments except Expt. 5, germinated seeds (radicle $1 \mathrm{~mm}$ or greater) were counted daily for $21 \mathrm{~d}$. Germinated seeds were discarded each day. In Expt. 5, 12 petri plates were kept in complete darkness. Four plates were selected at random and germinated seeds were counted at 7,14 , or $21 \mathrm{~d}$ after sowing. Seeds were discarded after counting. Concurrently, a control group of four petri plates was exposed to $12 \mathrm{~h}$ of irradiance per day, and germinated seeds were counted at 7,14 , and $21 \mathrm{~d}$ after sowing.

The final germination percentage at $21 \mathrm{~d}$ (G21), number of days to $50 \%$ final germination $\left(\mathrm{T}_{50}\right)$, and number of days between $10 \%$ and $90 \%$ germination $\left(\mathrm{T}_{90}-\mathrm{T}_{10}\right)$ were calculated for each treatment. Six experiments were conducted. All were performed as completely randomized designs.

Expt. 1: Effects of prestratification and cold stratification duration on germination responses. Seeds were sown in petri dishes on blotter paper moistened with deionized water and were prestratified (constant $20{ }^{\circ} \mathrm{C}$ and $12 \mathrm{~h}$ of irradiance per day) in the growth chamber for 0,2 , or 4 weeks. After prestratification, seeds were cold-stratified at $5 \pm$ $2{ }^{\circ} \mathrm{C}$ in a dark refrigerator (Precision 812; Precision Scientific, Chicago) for 0, 2.5, 5, 7.5 , or 10 weeks and were then returned to the $20{ }^{\circ} \mathrm{C}$ growth chamber for a poststratification period of $21 \mathrm{~d}$.

Expt. 2: Effects of gibberellic acid on germination responses. Seeds were sown in petri dishes containing blotter paper moistened with $\mathrm{GA}_{3}$ (grade III; Sigma-Aldrich Corp., St. Louis) at $0,1,10,100$, or 250 $\mathrm{mg} \cdot \mathrm{L}^{-1}$ in deionized water.

Expt. 3: Effects of potassium nitrate on germination responses. Seeds were sown in petri dishes on blotter paper moistened with $\mathrm{KNO}_{3}$ (Sigma-Aldrich Corp.) at 0, 1, 5, 10, 50 , or $100 \mathrm{~mm}$ in deionized water.

Expt. 4: Additive effects of $\mathrm{GA}_{3}$ and cold stratification on germination responses. Seeds received one of the following treatments: 1) stratification for 10 weeks at $5 \pm 2$ ${ }^{\circ} \mathrm{C}$ in the dark; 2) plus $\mathrm{GA}_{3}\left(10 \mathrm{mg} \cdot \mathrm{L}^{-1}\right.$ in deionized water) applied to seeds on the day of sowing; 3) cold stratification for 10 weeks at $5 \pm 2{ }^{\circ} \mathrm{C}$ plus $\mathrm{GA}_{3}\left(10 \mathrm{mg} \cdot \mathrm{L}^{-1}\right.$ in deionized water) applied to seeds on the day of transfer to germination conditions; or 4) untreated seed (control).

Expt. 5: Effects of light and darkness on germination responses. Seeds were sown on blotter paper moistened with deionized water. Petri dishes were sealed with parafilm after sowing. Seeds were incubated at constant $20{ }^{\circ} \mathrm{C}$. There were two treatments: 1) exposure to light from cool-white fluorescent lamps $\left(50 \pm 8 \mu \mathrm{mol} \cdot \mathrm{m}^{-2} \cdot \mathrm{s}^{-1} P P F\right)$ for $12 \mathrm{~h}$ daily; and 2) total darkness. petri dishes were wrapped in aluminum foil to exclude light.
Expt. 6: Seed disinfestation and pathology. Four groups of 20 seeds were used in each treatment. Seeds were treated with bleach (diluted with deionized water to $0.6 \% \mathrm{NaHClO}$ ) for 10 or $20 \mathrm{~min}$. Seeds were rinsed with sterile water and aseptically sown on acidified potato dextrose agar. Sterile conditions were maintained by sowing seeds under a laminar flow hood (Edgegard, Baker Co., Sanford, ME). Control seeds were rinsed with sterile water. Petri dishes were incubated for $3 \mathrm{~d}$ on a laboratory bench at ambient temperature $\left(\approx 18^{\circ} \mathrm{C}\right)$. Seeds were observed $3 \mathrm{~d}$ after sowing for the presence of fungi. Two additional replicates of 25 seeds per treatment were used for germination studies. Glass petri dishes and blotter paper were sterilized in an autoclave (Market Forge Sterilmatic, Everett, MA) at $121{ }^{\circ} \mathrm{C}$ and $103 \mathrm{kPa}$ for $15 \mathrm{~min}$. Seeds were sown under a laminar flow hood and petri dishes were transferred to the growth chamber for 21-d incubation. The experiment was repeated once.

Data analysis. The General Linear Models, analysis of variance, and $t$ test procedures of SAS (SAS Institute, Cary, NC) were used for data analysis. Coefficients for orthogonal polynomial comparisons were calculated using the IML procedure of SAS. Data from Expt. 5 were transformed (arcsin for G21 and square root for $\mathrm{T}_{50}$ and $\mathrm{T}_{90}-\mathrm{T}_{10}$ ) before analyses.

\section{Results and Discussion}

Expt. 1: Effects of prestratification and cold stratification. A significant interaction occurred between prestratification and cold stratification periods as shown in Figure 1. The prestratification period had a more pronounced effect on G21 when seeds were

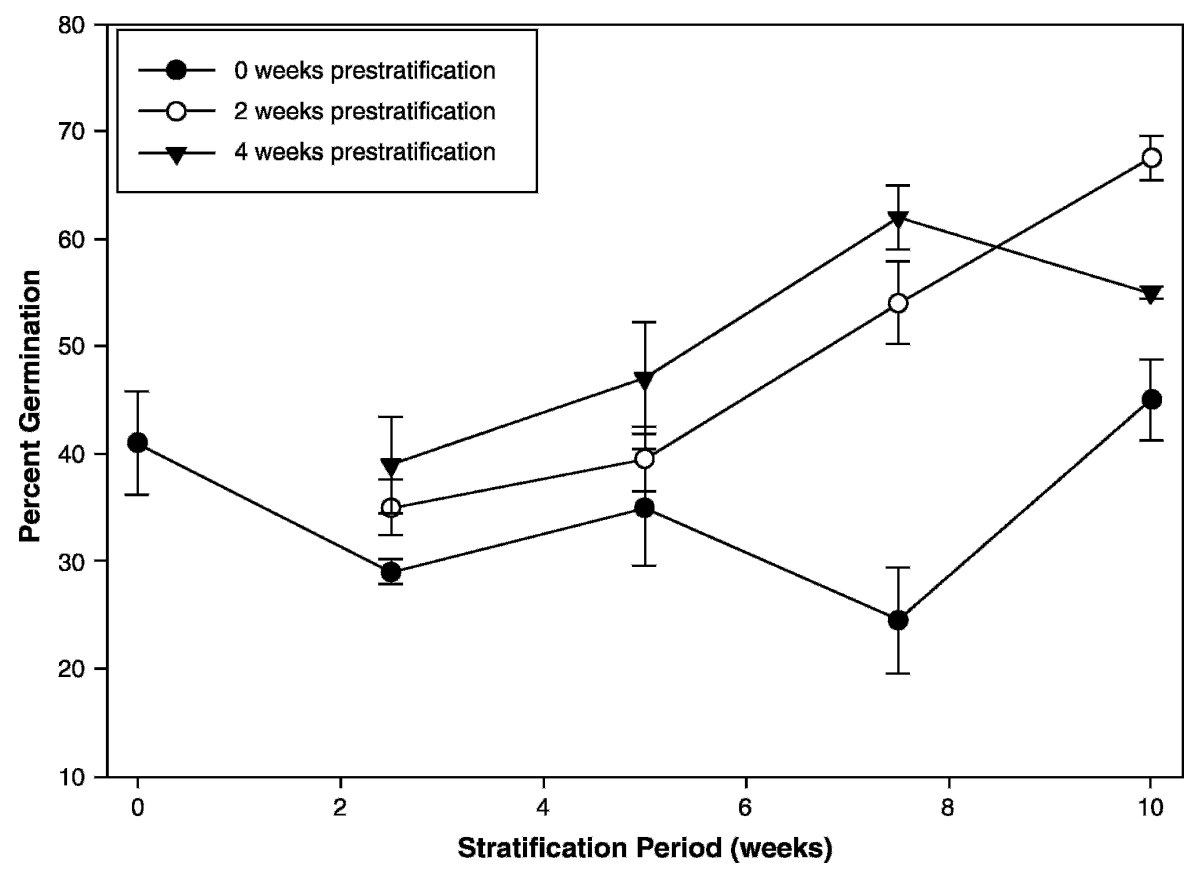

Fig. 1. Total germination percentage (G21) of cold-stratified Phlox pilosa seeds that received 0, 2, or 4 weeks prestratification at $20^{\circ} \mathrm{C}$. Standard error is represented by vertical bars. 
subsequently cold-stratified for longer periods. With 2 weeks prestratification, G21 increased linearly as the duration of cold stratification increased. With 4 weeks prestratification, G21 increased as the cold stratification period increased to 7.5 weeks but declined slightly when seeds were stratified for 10 weeks.

Prestratification at $20{ }^{\circ} \mathrm{C}$ for 2 to 4 weeks induced germination in $\approx 30 \%$ to $50 \%$ of the treated seeds (Table 1). An average of $34.5 \%$ of prestratified seeds germinated after 2 weeks at $20{ }^{\circ} \mathrm{C}$, whereas an average of $43.5 \%$ germinated after 4 weeks. An analysis of covariance (data not shown) revealed that increasing the prestratification period decreased the ameliorative effect of cold stratification on G21. Significance in the 0week prestratification category is artifactual because this group received no prestratification. Figures are presented in the interest of consistency.

The greatest total germination (67.5\%) was achieved with 2 weeks prestratification and 10 weeks of cold stratification (Table 1). Although this is a significant improvement over the control, prestratification followed by cold stratification may not be a practical method for greenhouse growers who will be interested in producing a crop of plants that are uniform in size. Seedlings obtained during prestratification will be larger than those obtained after 10 weeks of stratification.

Greene and Curtis (1950) observed that germination of Phlox pilosa seeds increased from $2 \%$ to $10 \%$ after stratification at $40{ }^{\circ} \mathrm{F}(6$ ${ }^{\circ} \mathrm{C}$ ) for 12 weeks. In the current study, G21 of seeds cold-stratified for 10 weeks without prestratification was $45 \%$, slightly higher than the G21 value for the control (0 weeks prestratification, 0 weeks cold stratification [Fig. 1]). It is possible that a period of cold stratification greater than 3 months with no prestratification is necessary for improvement of germination rate and uniformity in this species. Cold temperatures will keep nondormant seeds conditionally dormant (i.e., unable to germinate solely because of unfavorable temperature) while breaking dormancy in seeds with physiological dormancy.

In some temperate species, dormancy is broken by a period of warm temperatures followed by cold stratification. This response is most often associated with morphophysiological dormancy (Fenner and Thompson, 2005); however, seeds with morphophysiological dormancy have underdeveloped embryos (Baskin and Baskin, 2005). Dissection of $200 P$. pilosa seeds under a binocular stereoscope (Zeiss, Thornwood, NY) revealed fully developed embryos in $96 \%$ of the seeds (data not shown). Thus, it appears that the $P$. pilosa seeds used in this experiment vary in their level of physiological dormancy. Variation in depth of seed dormancy may be incited by environmental factors or positional effects while seeds are maturing on the mother plant. Length of day, temperature, light quality, age, and nutritional status of the parent plant, seed position in the fruit, and position of the fruit in the inflorescence have been reported to affect seed germinability (Gray and Thomas, 1982;

Table 1. Effects of prestratification and stratification on germination of Phlox pilosa seeds.

\begin{tabular}{|c|c|c|c|}
\hline $\begin{array}{l}\text { Stratification period } \\
\text { (weeks) }\end{array}$ & $\begin{array}{l}\text { Percent germination } \\
\text { prestratification }\end{array}$ & $\begin{array}{l}\text { Percent germination } \\
\text { poststratification }\end{array}$ & $\begin{array}{l}\text { Total percent } \\
\text { germination }\end{array}$ \\
\hline \multicolumn{4}{|c|}{0 weeks prestratification } \\
\hline 2.5 & 0.0 & 29.0 & 29.0 \\
\hline 5 & 0.0 & 35.0 & 35.0 \\
\hline 7.5 & 0.0 & 24.5 & 24.5 \\
\hline 10 & 0.0 & 45.0 & 45.0 \\
\hline \multicolumn{4}{|l|}{ Significance } \\
\hline Linear & NS & ** & * \\
\hline Quadratic & NS & * & NS \\
\hline Cubic & NS & $* * *$ & ** \\
\hline Mean & 0.0 & 33.4 & 33.4 \\
\hline \multicolumn{4}{|c|}{2 weeks prestratification } \\
\hline 2.5 & 30.5 & 4.5 & 35.0 \\
\hline 5 & 28.0 & 11.5 & 39.5 \\
\hline 7.5 & 38.0 & 16.0 & 54.0 \\
\hline 10 & 41.5 & 26.0 & 67.5 \\
\hline \multicolumn{4}{|l|}{ Significance } \\
\hline Linear & ** & $* * *$ & $* * *$ \\
\hline Quadratic & NS & NS & NS \\
\hline Cubic & NS & NS & NS \\
\hline Mean & 34.5 & 14.5 & 49.0 \\
\hline \multicolumn{4}{|c|}{4 weeks prestratification } \\
\hline 2.5 & 37.0 & 2.0 & 39.0 \\
\hline 5 & 43.0 & 4.0 & 47.0 \\
\hline 7.5 & 50.5 & 11.5 & 62.0 \\
\hline 10 & 43.5 & 11.5 & 55.0 \\
\hline \multicolumn{4}{|l|}{ Significance } \\
\hline Linear & NS & * & $* * *$ \\
\hline Quadratic & NS & NS & $*$ \\
\hline Cubic & NS & NS & NS \\
\hline Mean & 43.5 & 7.3 & 50.8 \\
\hline
\end{tabular}

Gutterman, 1982). Greene and Curtis (1950) observed a wide variation in germination between seed lots collected in different years. These investigators surmised that this variation involved the same factors that are affected by stratification, but do not discuss these factors further (Greene and Curtis, 1950).

Expt. 2: Effects of gibberellic acid. Exogenously applied $\mathrm{GA}_{3}$ had a significant effect on $\mathrm{G} 21, \mathrm{~T}_{50}$, and $\mathrm{T}_{90}-\mathrm{T}_{10}$ values. G21 values exhibited a generally positive quadratic response, whereas $\mathrm{T}_{50}$ and $\mathrm{T}_{90}-\mathrm{T}_{10}$ values showed positive and negative linear trends, respectively, to increasing $\mathrm{GA}_{3}$ concentrations (Table 2). Application of $10 \mathrm{mg} \cdot \mathrm{L}^{-1}$ $\mathrm{GA}_{3}$ increased the $\mathrm{G} 21$ percentage to $68.5 \%$, a significant improvement above the control. The $\mathrm{T}_{50}$ at $10 \mathrm{mg} \cdot \mathrm{L}^{-1}$ was similar to that of the control, whereas $\mathrm{T}_{50}$ increased markedly at $\mathrm{GA}_{3}$ concentrations greater than $10 \mathrm{mg} \cdot \mathrm{L}^{-1}$. A total of $10 \mathrm{mg} \cdot \mathrm{L}^{-1} \mathrm{GA}_{3}$ also shortened $\mathrm{T}_{90}-\mathrm{T}_{10}$ to $4.5 \mathrm{~d}, 3 \mathrm{~d}$ less than the control.

Gibberellins have been reported to stimulate germination in seeds with nondeep and intermediate physiological dormancy (Baskin and Baskin, 1998). The results of this experiment demonstrate that $\mathrm{GA}_{3}$ at 10 $\mathrm{mg} \cdot \mathrm{L}^{-1}$ shows promise as a practical method of improving the germination percentage, rate, and uniformity of $P$. pilosa.

Expt. 3: Effects of potassium nitrate. Overall, application of $\mathrm{KNO}_{3}$ had a significant negative effect on the G21 values (Table 3 ). These results are similar to those observed by Springer and Tyrl (1989) in their experiments with $P$. oklahomensis. $\mathrm{T}_{50}$ and $\mathrm{T}_{90}-\mathrm{T}_{10}$ values were unaffected significantly by the $\mathrm{KNO}_{3}$ concentrations used in this study.

Nitrate acts as a signal molecule promoting germination in seeds of Arabidopsis, possibly through interaction with GA or abscisic acid production pathways (Alboresi et al., 2005). Although $5 \mathrm{mM} \mathrm{KNO}_{3}$ improved germination of $P$. pilosa seeds above that of the control, the effect was marginal. Additional experiments are needed to test the effects of $\mathrm{KNO}_{3}$ concentrations between 1 and $10 \mathrm{mM}$.

Expt. 4: Additive effects of gibberellin-3 and cold stratification. Stratification and $\mathrm{GA}_{3}$ treatments interacted significantly to affect $\mathrm{G} 21, \mathrm{~T}_{50}$, and $\mathrm{T}_{90}-\mathrm{T}_{10}$ values. $\mathrm{GA}_{3}$ without stratification markedly enhanced G21 to $55.5 \%$, well above the control and other treatments, as shown in Figure 2A; however, the addition of $10 \mathrm{mg} \cdot \mathrm{L}^{-1} \mathrm{GA}_{3}$ to stratified seeds did not significantly alter G21. Stratification without $\mathrm{GA}_{3}$ had the most significant effect on the $\mathrm{T}_{50}$ value, reducing it to $4.75 \mathrm{~d}$, as shown in Figure 2B. Addition of $\mathrm{GA}_{3}$ to stratified seeds increased the $T_{50}$ value to $7 \mathrm{~d}$, a significant increase relative to stratification alone. Although the interaction between stratification and $\mathrm{GA}_{3}$ was significant for the $\mathrm{T}_{90^{-}}$ $\mathrm{T}_{10}$ value, the effects of $\mathrm{GA}_{3}$ on stratified and unstratified seeds were nonsignificant.

Expt. 5: Germination in light and darkness. Daily exposure of $P$. pilosa seeds to $50 \pm 8 \mu \mathrm{mol} \cdot \mathrm{m}^{-2} \cdot \mathrm{s}^{-1} P P F$ from coolwhite fluorescent lamps yielded germination 
Table 2. Final germination percentage at $21 \mathrm{~d}$ (G21), $\mathrm{T}_{50}$, and $\mathrm{T}_{90}-\mathrm{T}_{10}$ values for Phlox pilosa seeds treated with different concentrations of $\mathrm{GA}_{3}$.

\begin{tabular}{lccc}
\hline $\mathrm{GA}_{3}(\mathrm{mg} / \mathrm{L})$ & $\begin{array}{c}\text { Germination } \\
(\%)\end{array}$ & $\begin{array}{c}\mathrm{T}_{50} \\
(\text { days })^{\mathrm{z}}\end{array}$ & $\begin{array}{c}\mathrm{T}_{90}-\mathrm{T}_{10} \\
(\text { days })^{\mathrm{y}}\end{array}$ \\
\hline 0 & 44.0 & 8.5 & 7.5 \\
1 & 56.0 & 9.0 & 8.8 \\
10 & 68.5 & 8.5 & 4.5 \\
100 & 63.5 & 10.0 & 6.5 \\
250 & 48.5 & 12.3 & 4.8 \\
Significance & $* * *$ & $* *$ & $* *$ \\
Linear & $\mathrm{NS}$ & $* * *$ & $* *$ \\
Quadratic & $* * *$ & $\mathrm{NS}$ & $\mathrm{NS}$ \\
Cubic & $* * *$ & $\mathrm{NS}$ & $* * *$ \\
\end{tabular}

${ }^{\mathrm{z}} \mathrm{T}_{50}=$ number of days until $50 \%$ of final germination.

${ }^{\mathrm{y}} \mathrm{T}_{90-10}=$ number of days between $10 \%$ and $90 \%$ of final germination.

${ }_{\text {Ns, }}^{* *, * * *}$ Nonsignificant or significant at $P=0.01$ or 0.001 , respectively.

Table 3. Final germination percentage at $21 \mathrm{~d}$ (G21), $\mathrm{T}_{50}$, and $\mathrm{T}_{90}-\mathrm{T}_{10}$ values for Phlox pilosa seeds treated with different concentrations of $\mathrm{KNO}_{3}$.

\begin{tabular}{lccc}
\hline $\mathrm{KNO}_{3}(\mathrm{mM})$ & $\begin{array}{c}\text { Germination } \\
(\%)\end{array}$ & $\begin{array}{c}\mathrm{T}_{50} \\
(\text { days })^{\mathrm{z}}\end{array}$ & $\begin{array}{c}\mathrm{T}_{90}-\mathrm{T}_{10} \\
(\text { days })^{\mathrm{y}}\end{array}$ \\
\hline 0 & 37.0 & 10.5 & 11.8 \\
1 & 31.0 & 10.8 & 10.0 \\
5 & 41.5 & 10.3 & 9.0 \\
10 & 35.5 & 10.0 & 9.3 \\
50 & 22.5 & 11.3 & 9.8 \\
100 & 19.5 & 11.3 & 8.0 \\
Significance & $* *$ & $\mathrm{NS}$ & $\mathrm{NS}$ \\
Linear & $* * *$ & $\mathrm{NS}$ & $\mathrm{NS}$ \\
Quadratic & $\mathrm{NS}$ & $\mathrm{NS}$ & $\mathrm{NS}$ \\
Cubic & $\mathrm{NS}$ & $\mathrm{NS}$ & $\mathrm{NS}$ \\
\hline
\end{tabular}

${ }^{\mathrm{z}} \mathrm{T}_{50}=$ number of days until $50 \%$ of final germination.

${ }^{\mathrm{y}} \mathrm{T}_{90-10}=$ number of days between $10 \%$ and $90 \%$ of final germination.

Ns, **,*** Nonsignificant or significant at $P=0.01$ or 0.001 , respectively.

responses significantly greater than those seeds kept in total darkness (Table 4). Thus, we can conclude that light appears to be necessary for germination of this species at $20{ }^{\circ} \mathrm{C}$. These results differ from the observation of Carpenter et al. (1993b) that total germination percentage of $P$. drummondii seeds was unaffected by light or darkness. The seeds of most light-requiring species are physiologically dormant (Hartmann et al., 1997).

Expt. 6: Seed disinfestation and pathology. Disinfestation treatment had a significant effect on the presence of seedborne fungi (Table 5); however, it had no effect on the $\mathrm{G} 21$ or $\mathrm{T}_{50}$ values (data not shown). $\mathrm{T}_{90}-\mathrm{T}_{10}$ was not calculated. The majority of fungi identified on the seeds were Alternaria and Cladosporium species. Rare colonies of Fusarium were observed. It appears that seedborne fungi are not the cause of poor germination in this species.

\section{Conclusions}

This study describes a set of experiments on the germination requirements of Phlox pilosa seeds. Ten weeks of cold stratification

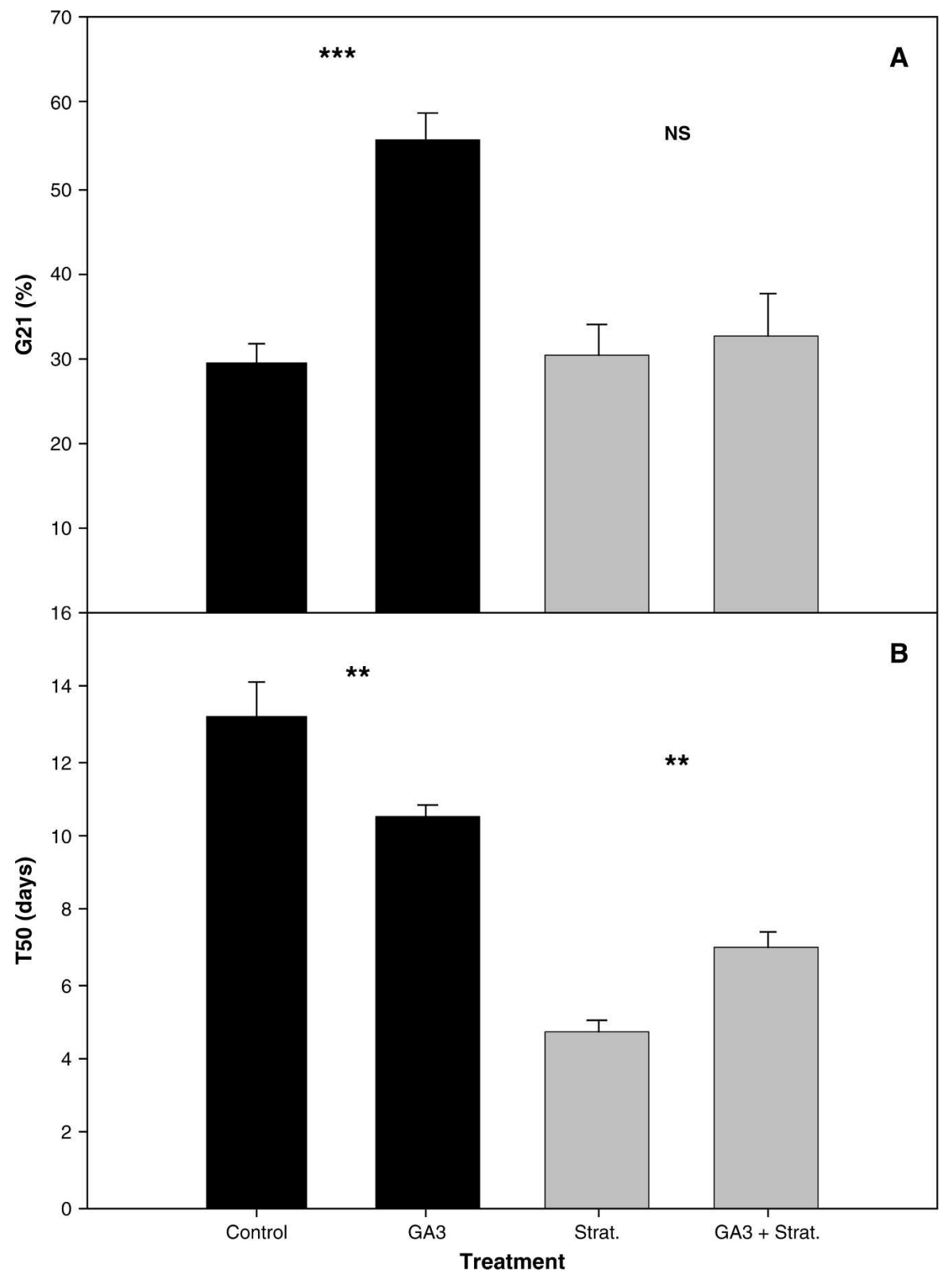

Fig. 2. Significance, as determined by $F$ test, of the additive effects of $\mathrm{GA}_{3}$ and stratification on $\mathrm{G} 21$ (A) and $\mathrm{T}_{50}$ (B) percentage of Phlox pilosa seeds. Strat $=$ stratification. Standard error is represented by vertical bars. ${ }^{\mathrm{NS},}{ }^{* * * * * *}$ Nonsignificant or significant at $P=0.01$ or 0.001 , respectively.

Table 4. Germination responses of Phlox pilosa seeds to light and darkness.

\begin{tabular}{lccc}
\hline $\begin{array}{l}\text { Days after } \\
\text { sowing }\end{array}$ & \multicolumn{2}{c}{ Germination (\%) } & \\
\cline { 2 - 3 } & Dark $^{z}$ & Light $^{y}$ & Significance \\
\hline 7 & 0.5 & 14.0 & $* * *$ \\
14 & 1.5 & 37.5 & $* *$ \\
21 & 2.5 & 44.5 & $* *$ \\
\hline
\end{tabular}

${ }^{2}$ Petri plates wrapped in parafilm and aluminum foil on the day of sowing and checked for germination at 7,14 , and $21 \mathrm{~d}$ after sowing.

${ }^{y}$ Petri plates wrapped in parafilm on the day of sowing and exposed to $50 \pm 8 \mu \mathrm{mol} \cdot \mathrm{m}^{-2} \cdot \mathrm{s}^{-1}$ photosynthetic photon flux for $12 \mathrm{~h}$ daily. Germination was recorded at 7, 14, and $21 \mathrm{~d}$ after sowing.

${ }^{* * * * * *}$ Significant at $P=0.01$ or 0.001 , respectively.

alone significantly decreased $\mathrm{T}_{50}$ in both Expts. 1 and 4, but did not improve G21. Total germination was improved to $67.5 \%$ after 2 weeks warm stratification and 10
Table 5. Effect of surface disinfestation with $0.6 \%$ sodium hypochlorite on the presence of seedborne fungi in Phlox pilosa.

\begin{tabular}{lccc}
\hline $\begin{array}{l}\text { Duration of } \\
\text { treatment } \\
\text { (minutes) }\end{array}$ & $\begin{array}{c}\text { Infected } \\
\text { seeds } \\
(\%)\end{array}$ & $\begin{array}{c}\text { Germination } \\
(\%)\end{array}$ & $\begin{array}{c}\mathrm{T}_{50} \\
(\text { days })^{2}\end{array}$ \\
\hline 0 & 100 & 23.0 & 10.25 \\
20 & 30 & 20.0 & 13.0 \\
40 & 8.75 & 23.0 & 12.0 \\
Significance & & & \\
$\quad$ Linear & $* * *$ & NS & NS \\
Quadratic & $* * *$ & NS & NS \\
\hline
\end{tabular}

${ }^{\mathrm{z}} \mathrm{T}_{50}=$ number of days until $50 \%$ of final germination.

${ }_{\text {Ns, } * * * *}$ Nonsignificant or significant at $P=0.001$.

weeks of cold stratification. This is a significant improvement over the control (41\%); however, a substantial amount of germination during the warm stratification period means that this method would produce a crop 
with poor uniformity. Because one of the objectives in plant propagation is to attain a uniform crop, prestratification combined with poststratification would not produce desirable results. The procedures used in Expt. 1 are similar to the germination instructions for P. pilosa seeds published by Jelitto Staudensamen (2004). Prairie Moon Nursery (2004) suggests cold stratification for 8 weeks without prestratification. The results of the current study suggest that this treatment is insufficient for improving germination of $P$. pilosa seeds. It is possible that a period of more than 10 weeks of cold stratification is necessary.

Overall, the greatest improvements in both germination and uniformity were obtained by the addition of $10 \mathrm{mg} \cdot \mathrm{L}^{-1} \mathrm{GA}_{3}$. This treatment improved germination to $68.5 \%$ and shortened $\mathrm{T}_{90}-\mathrm{T}_{10}$ to $4.5 \mathrm{~d}$. In Expt. $4, \mathrm{GA}_{3}$ significantly improved G21 over that obtained by 10 weeks of cold stratification, but did not improve G21 when added to stratified seeds. These results indicate that $10 \mathrm{mg} \cdot \mathrm{L}^{-1} \mathrm{GA}_{3}$ may have a practical application for the improvement of germination percentage and uniformity in Phlox pilosa.

Application of $\mathrm{KNO}_{3}$ at concentrations from 1 to $100 \mathrm{mM}$ failed to bring about a substantial increase in germination. Surface sterilization with $10 \%$ bleach significantly decreased the incidence of seedborne fungi but did not influence germination, leading to the conclusion that seedborne fungi are not the cause of poor germination in P. pilosa.

Light is necessary for germination of this species at $20{ }^{\circ} \mathrm{C}$. All of the germination experiments described were conducted at $20{ }^{\circ} \mathrm{C}$, but there is no evidence that this is the optimum temperature for germination of this species. Except for the seeds kept in complete darkness in Expt. 4, all experiments used a 12-h photoperiod. Further experimentation is warranted to determine the germination responses of $P$. pilosa seeds at different temperatures and photoperiods (Specialty Perennials, 2006).

\section{Literature Cited}

Alboresi, A., C. Gestin, M.-T. Leydecker, M. Bedu, C. Meyer, and H.-N. Truong. 2005. Nitrate, a signal relieving seed dormancy in Arabidopsis. Plant Cell Environ. 28:500-512.

Association of Official Seed Analysts (AOSA). 1988. Rules for testing seeds. J. Seed Technol. 12(3).

Barkley, T.M. (ed.). 1986. Flora of the great plains. University Press of Kansas, Lawrence, KS.

Baskin, C.C. and J.M. Baskin. 1998. Seeds: Ecology, biogeography, and evolution of dormancy and germination. Academic Press, Boston, MA.
Baskin, C.C. and J.M. Baskin. 2005. Seed dormancy in wild flowers, p. 163-185. In: McDonald, M.B. and F.Y. Kwong (eds.). Flower seeds: Biology and technology. CABI Publishing, Cambridge, MA.

Batak, I., M. Devi, Z. Giba, D. Grubisi, K.L. Poff, and R. Konjevic. 2002. The effects of potassium nitrate and NO-donors on phytochrome A- and phytochrome B-specific induced germination of Arabidopsis thaliana seeds. Seed Sci. Res. 12:253-259.

Bewley, J.D. 1997. Seed germination and dormancy. Plant Cell 9:1055-1066.

Bewley, J.D. and M. Black. 1994. Seeds: Physiology of development and germination. 2nd ed. Plenum Press, New York.

Bratcher, C.B., J.M. Dole, and J.C. Coleman. 1993. Stratification improves seed germination of five native wildflower species. HortScience 28: 899-901.

Carpenter, W.J., E.R. Ostmark, and J.A. Cornell. 1993a. Temperature and seed moisture govern storage duration and germination of Phlox drummondii. HortScience 28:185-188.

Carpenter, W.J., E.R. Ostmark, and J.A. Cornell. 1993b. The role of light during Phlox drummondii Hook. seed germination. HortScience 28:786-788.

Carpenter, W.J., E.R. Ostermark, and J.A. Cornell. 1995. Evaluation of temperature and moisture content during storage on the germination of flowering annual seed. HortScience 30:10031006.

Christiansen, P.A. 1967. Establishment of prairie species in Iowa by seeding and transplanting. University of Iowa, PhD Diss.

Fenner, M. and K. Thompson. 2005. The ecology of seeds. Cambridge University Press, New York.

Gray, D. and T.H. Thomas. 1982. Seed germination and seedling emergence as influenced by the position of development of the seed on, and chemical applications to, the parent plant, $\mathrm{p}$. 81-110. In: Khan, A.A. (ed.). The physiology and biochemistry of seed development, dormancy and germination. Elsevier Biomedical Press, New York.

Greene, H.C. and J.T. Curtis. 1950. Germination studies of Wisconsin prairie plants. American Midland Naturalist 43:186-194.

Groot, S.P.C. and C.M. Karssen. 1987. Gibberellins regulate seed germination in tomato by endosperm weakening: A study with gibberellin deficient mutants. Planta 171:525-531.

Gutterman, Y. 1982. Phenotypic maternal effect of photoperiod on seed germination, p. 67-79. In Khan, A.A. (ed.). The physiology and biochemistry of seed development, dormancy and germination. Elsevier Biomedical Press, New York.

Halmer, P. 2000. Commercial seed treatment technology, p. 257-286. In: Black, M. and J.D. Bewley (eds.). Seed technology and its biological basis. CRC Press LLC, Boca Raton, FL.

Hamrick, D. 2005. Ornamental bedding plant industry and plug production, p. 27-38. In: McDonald, M.B. and F.Y. Kwong (eds.).
Flower seeds: Biology and technology. CABI Publishing, Cambridge, MA.

Hartmann, H.T., D.E. Kester, F.T. Davies, Jr. and R.L. Geneve. 1997. Plant propagation: Principles and practices. 6th ed. Prentice Hall, Upper Saddle River, NJ.

Heit, C.E. 1957. Laboratory germination of annual Phlox seeds. Proc. of the Assn. of Official Seed Analysts 47:154-157.

Hilhorst, H.W.M. and C.M. Karssen. 1988. Dual effect of light on the gibberellin- and nitratestimulated seed germination of Sisymbrium officinale and Arabidopsis thaliana. Plant Physiol. 86:591-597.

Jelitto Staudensamen. 2004. Price list 2004. Jelitto Staudensamen GmbH, Schwarmstedt, Germany.

Levin, D.A. 1966. The Phlox pilosa complex: Crossing and chromosome relationships. Brittonia $18: 142-162$.

Milstein, G.P. 2005. The uses and potential of wildflower seed in landscaping, p. 39-51. In: McDonald, M.B. and F.Y. Kwong (eds.) Flower seeds: Biology and technology. CABI Publishing, Cambridge, MA.

Mycock, D.J. and P. Berjak. 1995. The implications of seed-associated mycoflora during storage, p. 747-766. In: Kigel, J. and G. Galili (eds.). Seed development and germination. Marcel Dekker, Inc., New York.

Prairie Moon Nursery. 2004. Seed catalog. Prairie Moon Nursery, Winona, MT

Specialty Perennials. 2006. Seed catalog. Specialty Perennials, Apple Valley, MN. 13 Feb. 2006. <www.hardyplants.com>.

Springer, T.L. and R.J. Tyrl. 1989. Distribution, habitat and reproductive biology of Phlox oklahomensis Wherry (Polemoniaceae). Proc. of the Oklahoma Acad. of Sci. 69:15-21.

Steffey, J. 1987. Strange relatives: The Phlox family. American Horticulturist 66:5-9.

Wang, R., M. Okamoto, X. Xing, and N.M. Crawford. 2003. Microarray analysis of the nitrate response in Arabidopsis roots and shoots reveals over 1,000 rapidly responding genes and new linkages to glucose, trehalose-6-phosphate, iron, and sulfate metabolism. Plant Physiol. 132:556-567.

Wartidiningsih, N., R.L. Geneve, and S.T. Kester. 1994. Osmotic priming or chilling stratification improves seed germination of purple coneflower. HortScience 29:1445-1448.

Wherry, E.T. 1955. The Genus Phlox. Morris arboretum monographs III. Philadelphia, PA.

Yamaguchi, S. and Y. Kamiya. 2000. Gibberellin biosynthesis: Its regulation by endogenous and environmental signals. Plant Cell Physiol. 41:251-257.

Yamaguchi, S. and Y. Kamiya. 2002. Gibberellins and light-stimulated germination. J. Plant Growth Regul. 20:369-376.

Yamauchi, Y., M. Ogawa, A. Kuwahara, A. Hanada, Y. Kamiya, and S. Yamaguchi. 2004. Activation of gibberellin biosynthesis and response pathways by low temperature during imbibition of Arabidopsis thaliana seeds. Plant Cell 16:367-378. 